\title{
PENGARUH BERKUMUR LARUTAN DAUN BINAHONG (ANREDERA CORDIFOLIA) TERHADAP PH SALIVA PADA IBU HAMIL DI DESA PABENTENGAN KECAMATAN MARUSU KABUPATEN MAROS
}

\author{
Hj. NURHAENI
}

\begin{abstract}
ABSTRAK
Daun Binahong merupakan tanaman yang mempunyai khasiat untuk menyembuhkan penyakit. Untuk penggunaannya dapat dikunyah atau dimasak dengan segelas air. Khasiat dari daun ini dapat digunakan sebagai obat herbal. Daun binahong ini dapat digunakan untu pengobatan luar. Adapun larutan kumur yang dinilai lebih murah dan lebih efisien, ramah lingkungan, mudah didapat, serta memiliki efek samping yang minimal adalah larutan kumur yang terbuat dari bahan alami. Daun binahong mudah ditemukan dan sudah dikenal masyarakat karena sebagai salah satu tanaman obat keluarga. Daun binahong sering digunakan sebagai obat tradisional yang memiliki khasiat untuk mencegah penyakit stroke dan asam urat. Pada penelitian sebelumnya menjelaskan tentang rasa pahit yang terdapat pada daun binahong dapat merangsang kecepatan sekresi yang mempengaruhi derajat asam $\mathrm{pH}$ saliva dalam mulut karena sistem buffer dan menetralkan penurunan $\mathrm{pH}$ saliva.
\end{abstract}

Kata Kunci : Obat Kumur, Binahong, Anredera cordofolia

\section{PENDAHULUAN}

Data Riskesdas tahun 2007 menyebutkan bahwa prevalensi Nasional masalah Gigi-Mulut adalah 23,5\%. Data Riskesdas tahun 2013 Prevalensi Nasional Masalah Gigi-Mulut adalah 25,9\% penduduk Indonesia mempunyai masalah kesehatan gigi dan mulut atau meningkat dari data Riskesdas tahun 2007. Dan Sulawesi Selatan masukdalam daftar 3 provinsi yang mempunyai masalah gigi dan mulut yang cukup tinggi (>35\%), yaitu dengan masalah kesehatan gigi dan mulut sebanyak $36,2 \%$, dan yang menerima perawatan dari tenaga medis 10,3\%. (Riskesdas, 2007; Riskesdas, 2013).

Menurut Houwink, dkk (1993) setelah makan khususnya makanan karbohidrat, maka akan terjadi fermentasi terhadap glukosa makanan. Hasilnya berupa senyawa bersifat asam dan membuat lingkungan sekitar gigi bersuasana asam. Dalam beberapa menit derajat keasaman tadi akan meningkat atau pHnya turun. Bila berlanjut, penurunan nilai pH akan sampai ke nilai $\mathrm{pH}$ kritis, yaitu nilai $\mathrm{pH}$ yang dapat memicu dekalsifikasi (hilangnya garam kalsium) pada email gigi. Keberadaan perubahan suasana pHakan kembali normal setelah 20-30 menit kemudian. Dan selama 5-10 menit pertama setelah makan adalah saat-saat kritis $\mathrm{pH}$.

Pada masa kehamilan terjadi peningkatan hormon estrogen dan progesteron yang diikuti pola perubahan pemeliharaan kebersihan gigi dan mulut menjadi buruk. Perubahan ini disebabkan oleh timbulnya mual dan muntah yang akan membuat ibu hamil malas menggosok gigi. Atau ibu 
terlalu lemah dan lelah dengan kehamilannyasehingga malas menggosok gigi. Keadaan ini dengan sendirinya akan menambah penumpukan plak sehingga memperburuk kondisi dalam mulut termasuk peningkatan asam pada saliva. (Ritha, 2002)

Untuk mencegah ketidakseimbangan asam di dalam rongga mulut menurut Houwink, dkk (1993), dapat dilakukan dengan mencegah terbentuknya plak. Pencegahan dapat dilakukan dengan berbagai cara, antara lain secara mekanis maupun kimiawi. Pencegahan secara mekanik dilakukan dengan menggunakan sikat gigi. Sedangkan pencegahan secara kimiawi antara lain dengan menggunakan larutan kumur. Penggunaan larutan kumur adalah salah satu cara yang dianggap cukup berhasil dalam menjaga kebersihan rongga mulut. Larutan kumur yang digunakan untuk mencegah karies biasanya mengandung bahan kimia berbahaya yang memiliki efek merugikan jika digunakan dalam jangka waktu yang lama. Salah satunya mulut menjadi kering.

Pada penelitian sebelumnya menjelaskan tentang rasa pahit yang terdapat pada daun binahong dapat merangsang kecepatan sekresi yang mempengaruhi derajat asam pHsaliva dalam mulut karena sistem buffer dapat menetralkan penurunan pH saliva. (Istiqomah, Santoso, 2015)

Penelitian ini akan dilakukan di desa Pabentengan yang berlokasi sekitar $\pm 3 \mathrm{~km}$ dari jalan poros Makassar-Maros.Peneliti memilih desa tersebut dengan alasan karena peneliti menetap dan bertempat tinggal di desa ini, jadi memudahkan untuk melakukan penelitian serta mudah dijangkau oleh peneliti. Desa Pabentengan merupakan salah satu desa yang masuk dalam wilayah kerja Puskesmas Marusu Kecamatan Marusu Kabupaten Maros,yang membawahi 5 (lima) dusun, yaitu dusun Sossoe, dusun Ujung Bulo, dusun Kaemba, dusun Kaemba Jaya dan dusun Tambayangan. Dimana ibu hamilnya berjumlah 35 orang, yaitu di dusun Sossoe 3 orang, dusun Ujung Bulo 15 orang, dusun Kaemba 10 orang, dusun Kaemba Jaya 4 orang dan dusun Tambayangan 4 orang. Dimana ibu hamil lebih banyak memeriksakan kehamilannya dibandingkan dengan memeriksakan kesehatan gigi dan mulut. lbu hamil yang berkunjung ke poli gigi datang dengan keluhan kesehatan gigi dan mulut yang dialami misalnya gigi berlubang atau gusi bengkak dan berdarah.

\section{METODE PENELITIAN}

Jenis penelitian yang dilakukan menggunakan metode penelitian deskriptif kuantitatif dengan metode quasi eksperiment. Desain penelitian dengan pre and post test group desain yaitu pengukuran $\mathrm{pH}$ saliva sebelum dan sesudah berkumur larutan daun binahong.. Populasi dalam penelitin ini adalah ibu hamil di desa Pabentengan Kecamatan Marusu Kabupaten Maros. Sampel dalam penelitian ini diambil secara total sampling oleh peneliti. Dimana ibu hamil di desa Pabentengan Kecamatan Marusu Kabupaten Maros berjumlah 35 orang. Variabel Independen dalam penelitian ini adalah larutan daun Binahong, sedangkan variabel dependen yaitu pH Saliva Pada Ibu Hamil.

\section{HASIL PENELITIAN}

Penelitian dengan berjudul "Pengaruh Berkumur Larutan Daun Binahong (Anredera Cordifolia) Terhadap pH Saliva Pada Ibu Hamil Di Desa Pabentengan Kecamatan Marusu Kabupaten Maros" yang berlangsung selama 2 (dua) minggu lebih. Dengan jumlah sampel yang diperiksa sebanyak 33 orang dari jumlah sampel yang seharusnya 35 orang terdapat 2 orang yang 
tidak bersedia.Adapun lokasi yang dijadikan empat penelitian yaitu di dusun Sossoe 3 orang, dusun Ujung Bulo 15 orang, dusun Kaemba 10 orang, dusun Kaemba Jaya 4 orang dan dusun Tambayangan 4 orang. Dari jumlah sampel 33 diperoleh hasil sebagai berikut :

Tabel 4.1Distribusi pH Saliva Pada Responden Sebelum Berkumur Air Larutan Daun Binahong (Anredera Cordifolia).

\begin{tabular}{|l|l|l|}
\hline pH saliva & $\mathbf{n}$ (Jumlah) & Persentase (\%) \\
\hline Asam & 30 & $91 \%$ \\
\hline Netral & 2 & $6 \%$ \\
\hline Basa & 1 & $3 \%$ \\
\hline Jumlah & 33 & $100 \%$ \\
\hline
\end{tabular}

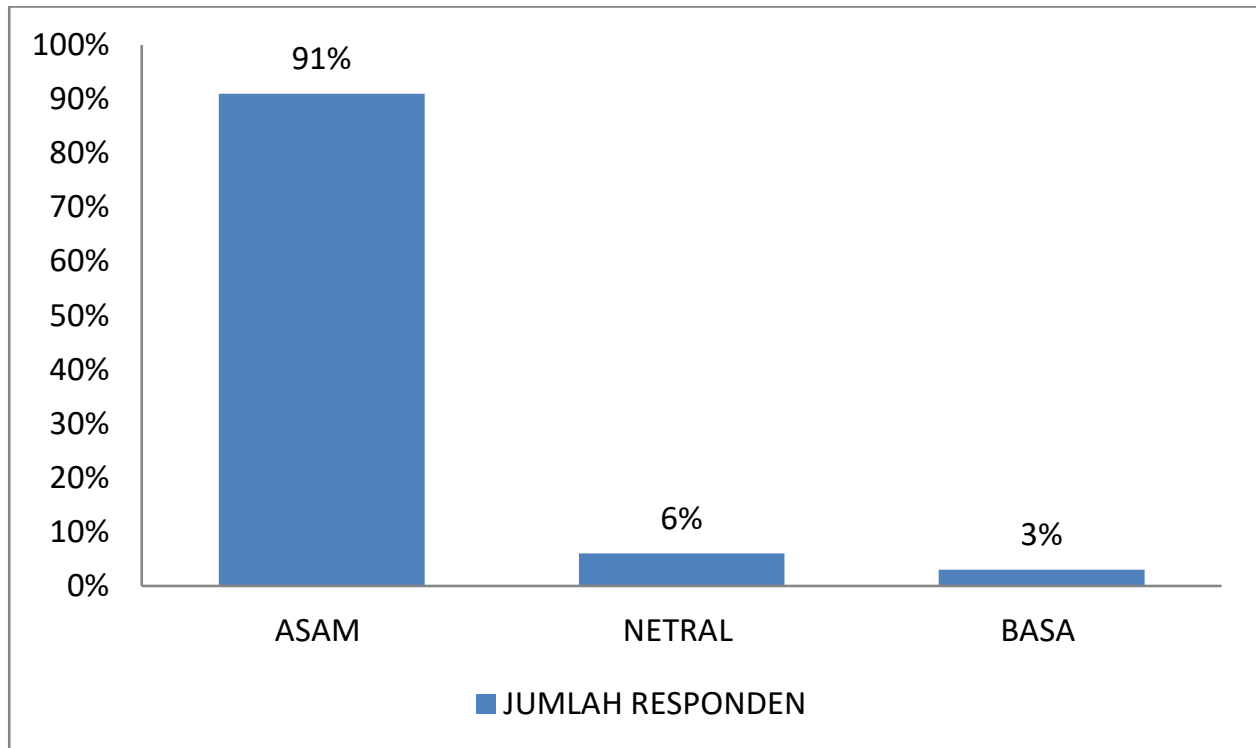

Gambar 4.1 DistribusipH Saliva Pada Responden Sebelum Berkumur Larutan Daun Binahong (Anredera Cordifolia)

Tabel dan gambar 4.1 menunjukkan bahwa 30 responden (91\%) sebelum berkumur larutan daun binahong mempunyai $\mathrm{pH}$ saliva dalam kriteria asam, 2 responden
(6\%) yang berada dalam kriteria netral dan 1 responden (3\%) yang kriteria basa sebelum berkumur larutan daun binahong. 
Tabel 4.2Distribusi pH Saliva Pada Responden Sesudah Berkumur Larutan Daun Binahong(Anredera Cordifolia)

\begin{tabular}{|c|c|c|}
\hline \multicolumn{2}{|c|}{ Larutan Daun Binahong(Anredera Cordifolia) } \\
\hline pH saliva & n (Jumlah) & Persentase (\%) \\
\hline Asam & 18 & \\
\hline Netral & 8 & $24 \%$ \\
\hline Basa & 7 & $21 \%$ \\
\hline Jumlah & 33 & $\mathbf{1 0 0} \%$ \\
\hline Sumber: Data Primer, Tahun 2019 & \\
\hline
\end{tabular}

Sumber: Data Primer, Tahun 2019

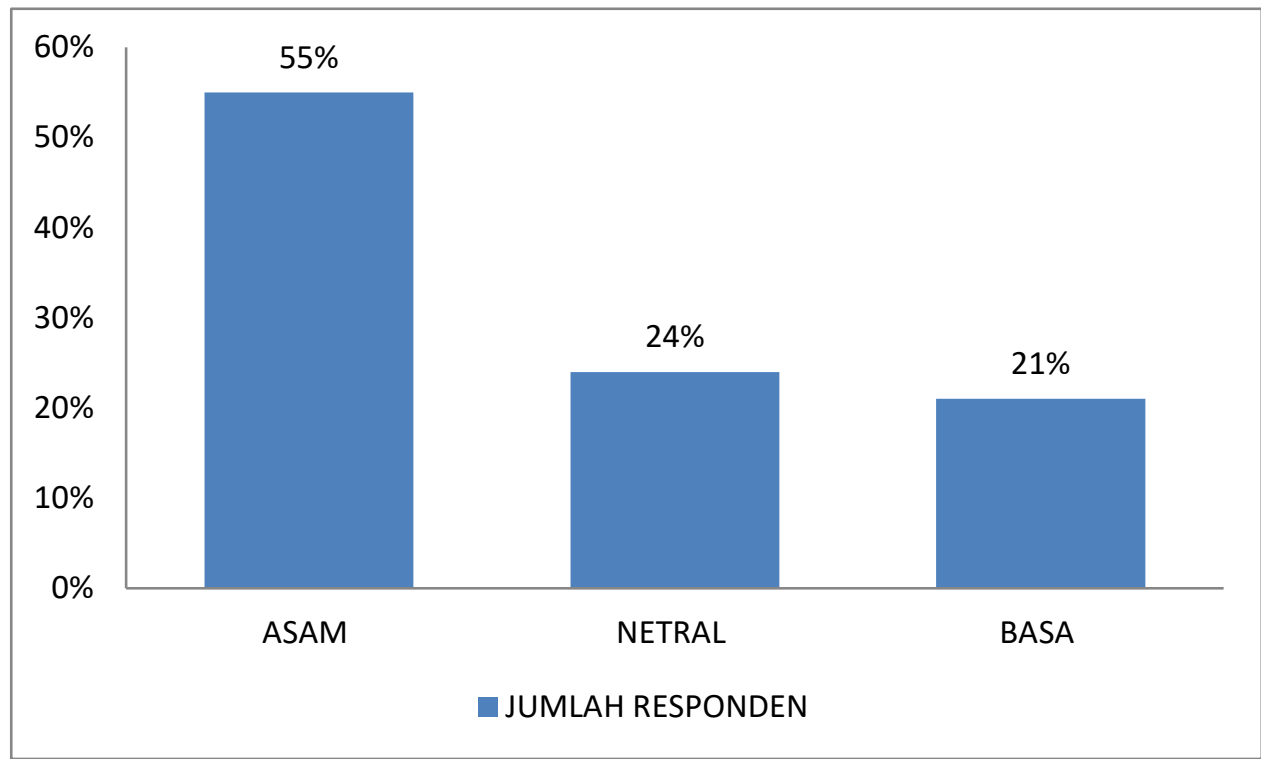

Gambar 4.2 Distribusi pH Saliva Pada Responden Sesudah Berkumur Larutan Daun Binahong (Anredera Cordifolia)

Tabel dan gambar 4.2 menunjukkan bahwa 18 responden (55\%) sesudah berkumur larutan daun binahong mempunyai $\mathrm{pH}$ saliva dalam kriteria asam, 8 responden (24\%) yang berada dalam kriteria netral dan 7 responden (21\%) yang kriteria basa sesudah berkumur larutan daun binahong. 
Tabel 4.3Distribusi pH Saliva Pada Responden Sebelum dan Sesudah Berkumur Larutan Daun Binahong (Anredera Cordifolia)

\begin{tabular}{|c|c|c|c|c|}
\hline \multirow{2}{*}{ Kriteria } & \multicolumn{2}{|c|}{ Sebelum Berkumur } & \multicolumn{2}{l|}{ Sesudah Berkumur } \\
\cline { 2 - 5 } & N (Jumlah) & Presentase (\%) & N (Jumlah) & $\begin{array}{l}\text { Presentase } \\
(\%)\end{array}$ \\
\hline Asam & 30 & $91 \%$ & 18 & $55 \%$ \\
\hline Netral & 2 & $6 \%$ & 8 & $24 \%$ \\
\hline Basa & 1 & $3 \%$ & 7 & $\mathbf{1 0 0 \%}$ \\
\hline Jumlah & 33 & $\mathbf{1 0 0 \%}$ & 33 & \\
\hline
\end{tabular}

Sumber: Data Primer, Tahun 2019

\section{JUMLAH RESPONDEN}

Sebelum Berkumur

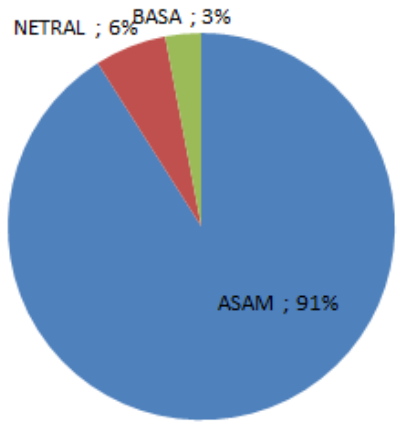

Sesudah Berkumur

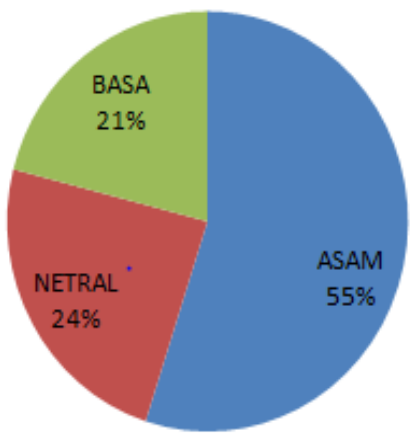

Gambar 4.3 Distribusi pH Saliva Pada Responden Sebelum dan Sesudah Berkumur Larutan Daun Binahong (Anredera Cordifolia)

Tabel dan gambar 4.3 menunjukkan bahwa terdapat perbedaan antara $\mathrm{pH}$ saliva sebelum dan sesudah berkumur larutan daun binahong (Anredera Cordifolia), sebelum berkumur $\mathrm{pH}$ saliva asam sebanyak 30 responden $(91 \%)$, dengan kriteria netral sebanyak 2 responden (6\%) dan kriteria basa sebanyak1 responden (3\%) dan setelah berkumur terjadi perubahan $\mathrm{pH}$ saliva walaupun masih dalam kriteria asamsebanyak 18 responden (55\%), kriteria netral 8 responden (24\%), dan kriteria basa sebanyak 7 responden (21\%). 
Tabel 4.4 Statistik Deskriptif

\begin{tabular}{|l|l|l|l|l|l|l|}
\hline & N & Minimum & Maximum & Sum & Mean & Std. Deviation \\
\hline $\begin{array}{l}\text { pH Saliva Sebelum } \\
\text { berkumur }\end{array}$ & 33 & 5.01 & 7.32 & 199.10 & 6.0333 & 0.51425 \\
\hline $\begin{array}{l}\text { pH Saliva Sesudah } \\
\text { berkumur }\end{array}$ & 33 & 6.15 & 8.31 & 226.06 & 6.8503 & 0.46080 \\
\hline Valid N (listwise) & 33 & & & & & \\
\hline
\end{tabular}

Sumber: Hasil Pengolahan Data, Tahun 2019

Tabel di atas menjelaskan deskriptif data $\mathrm{pH}$ saliva secara umum.Pada $\mathrm{pH}$ saliva sebelum dengan jumlah data sebanyak 33 orang menunjukkan rata-rata nilai sebesar 6,033 dengan standar deviasi sebesar 0.51425.Begitupun pada $\mathrm{pH}$ saliva setelah dengan jumlah data sebanyak 33 orang menunjukkan rata-rata nilai sebesar 6.8503 dengan standar deviasi sebesar 0.46080 . Nilai rata-rata $\mathrm{pH}$ saliva sesudah lebih besar dari $\mathrm{pH}$ saliva sebelum menunjukkan bahwa terdapat peningkatan nilai.

Tabel 4.5Hasil Analisis Uji T

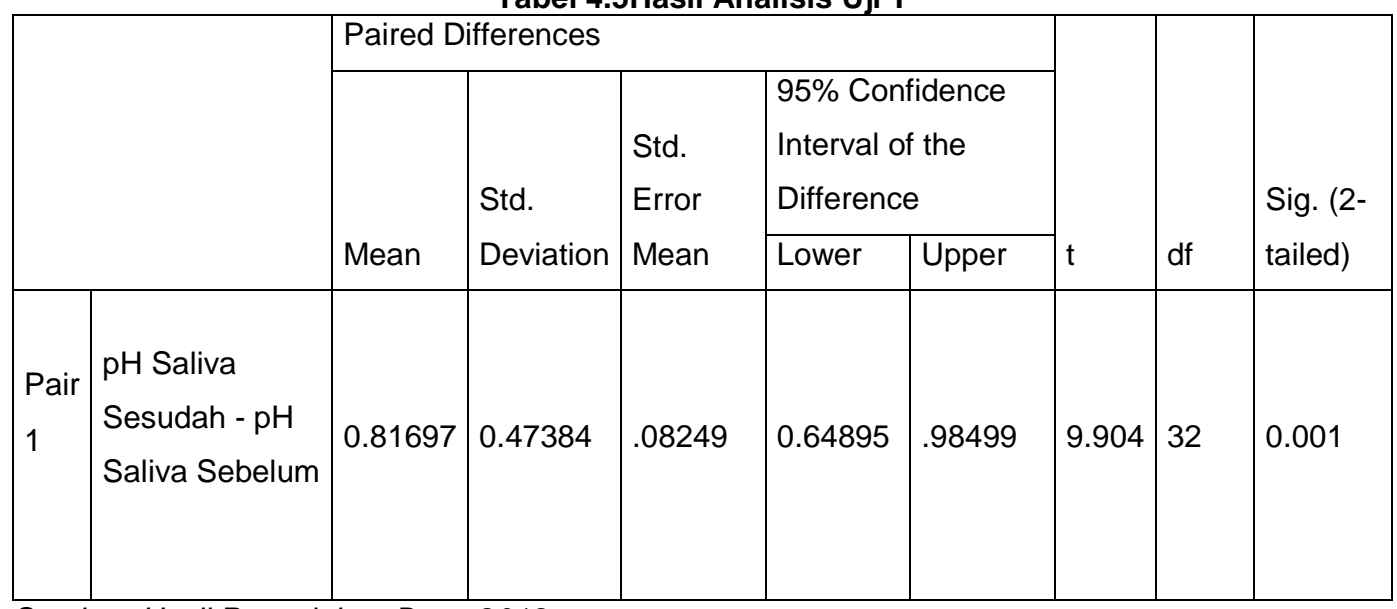

Sumber: Hasil Pengolahan Data, 2019

\section{PEMBAHASAN}

Dari hasil penelitian dengan judul pengaruh berkumur larutan daun binahong (Anredera Cordifolia) terhadap $\mathrm{pH}$ saliva pada ibu hamil di Desa Pabentengan Kecamatan Marusu Kabupaten Maros.Dimana pada tabel dan gambar 4.1 menunjukkan $\mathrm{pH}$ saliva sebelum berkumur larutan daun binahong pada ibu hamil berada pada kriteria asam 30 responden (91\%), 2 responden (6\%) yang berada dalam kriteria netral dan 1 responden (3\%) yang kriteria basa, hal ini disebabkan karena pada masa kehamilan terjadi perubahan fisiologis yang mengakibatkan terjadinya penurunan $\mathrm{pH}$ saliva dan pada trimester I (masa kehamilan 0-3 bulan) ibu hamil biasanya akan merasa lesu, mual dan kadang-kadang sampai muntah. Lesu, mual dan muntah ini dapat menyebabkan terjadinya peningkatan suasana asam di dalam mulut (Kemenkes, 2012). 


Selain itu karena Faktor perubahan
pada sistem gastrointestinal, sistem
gastroinstestinal
beberapa hal karena kehamilan. Dan
menurut penelitian terdahulu oleh Ritha
(2002) terjadinya peningkatan horrmon estrogen danprogesterone yang dapat mengganggu keseimbangan cairan tubuh, meningkatkan sirkulasi darah, dan melambatkan kontraksi otot-otot saluran pencernaan. Menyebabkan sekresi saliva menjadi lebih asam. Serta terjadi regurgitasi sehingga mulut terasa asam (Bandiyah, 2009)

Derajat keasaman dan kapasitas buffer disebabkan oleh susunan bikarbonat, yang meningkat sesuai dengan kecepatan sekresi. Hal ini dapat diartikan bahwa $\mathrm{pH}$ dan kapasitas buffer saliva meningkat sesuai dengan kenaikan laju kecepatan sekresi saliva. Bagian-bagian saliva lainnya, seperti fosfat (terutama HPO42) dan protein, hanya merupakan tambahan sekunder pada kapasitas buffer. Ureum pada saliva dapat digunakan oleh mikroorganisme pada rongga mulut dan menghasilkan pembentukan amonia. Amonia tersebut akan menetralkan hasil akhir asam metabolisme bakteri, sehingga $\mathrm{pH}$ menjadi lebih tinggi. (Amerongen, 1991)

Tabel dan gambar 4.2 menunjukkan bahwa 18 responden (55\%) sesudah berkumur larutan daun binahong mempunyai $\mathrm{pH}$ saliva dalam kriteria asam, 8 responden (24\%) yang berada dalam kriteria netral dan 7 responden (21\%) dapat dilihat bahwa terjadi penurunan $\mathrm{pH}$ saliva dari $91 \%$ sebelum berkumur larutan daun binahong menjadi 55\% setelah berkumur, namun tetap dalam kondisi asam ini dikarenakan asam atau basanya suatu cairan tubuh yang dapat berubah karena kecepatan aliran saliva,mikroorganisme rongga mulut, dan kapasitas buffer saliva. Kecepatan sekresi saliva dapat secara langsung mempengaruhi $\mathrm{pH}$ dalam mulut, jika kecepatan sekresi saliva meningkat maka $\mathrm{pH}$ saliva akan meningkat, sebaliknya menurunnya kecepatan sekresi saliva akan menurunkan $\mathrm{pH}$ saliva (Amerongen, 1991).

Adapun Faktor yang dapat menyebabkan berkurangnya aliran saliva antara lain: efek radiasi, perubahan hormonal (menopause), Faktor psikologi (takut, cemas, stress), penyakit pada kelenjar saliva (Sindroma Sjogren, parotitis), dan obatobatan. Obat yang mempunyai efek samping yang dapat menyebabkan berkurangnya sekresi saliva yaitu: antikolinergik, analgetik, antihistamin, antihipertensi, amfetamin, atrofin. Selain itu diet karbohidrat dapat menurunkan kapasitas penyangga saliva karena dengan adanya karbohidrat dapat terjadi peningkatan produksi asam oleh bakteri. Kapasitas penyangga saliva dapat meningkat ketika banyak mengkonsumsi diet kaya protein dan sayuran.Bakteri memanfaatkan protein sebagai sumber makanannya sehingga menghasilkan zat-zat yang bersifat basa seperti amoniak.

Kidd dan Bechal (1992)Mengatakan makanan yang kita konsumsi sehari-hari dapat mempengaruhi perubahan $\mathrm{pH}$ saliva di dalam rongga mulut, terutama makanan yang bersifat asam akan cenderung menyebabkan perubahan $\mathrm{pH}$ saliva menjadi turun dan bersifat asam pula. Selain itu, hasil metabolisme karbohidrat oleh mikroorganisme dalam rongga mulut juga akan menghasilkan asam yang akan memicu proses demineralisasi enamel dan dentin, 
sehingga akan memicu terjadinya karies.Produksi asam dari mikroorganisme yang ada pada plak gigi akan terus berlangsung selama proses metabolisme karbohidrat.Kurva Stephan menunjukkan penurunan tajam keasaman plak gigi setelah konsumsi karbohidrat. Bakteri plak akan memfermentasi karbohidrat (terutama gula dan amilum) dan akan menghasilkan asam, ion $\mathrm{H}$ pada asam akan menggantikan ikatan Ca pada hidroksi apatit dalam email.

Keasaman plak akan mengalami perubahan dari asam menjadi normal dalam beberapa menit tergantung dari jumlah dan komposisi saliva. Saliva yang mempunyai viskositas tinggi, sedikit komponen anorganik dan banyak musin akan membuat plak gigi menjadi semakin lengket. Plak gigi ini akan membuat sisa makanan dan bakteri terjebak di dalamnya. Aliran saliva yang sedikit akan menyulitkan pembersihan gigi dari plak yang terbentuk. Dalam hal ini sistem bufer sangat berperan sehingga dapat terjadi keseimbangan $\mathrm{pH}$ dalam rongga mulut.

Menurut penelitian terdahulu (Kusumasari, 2012) keasaman ( $\mathrm{pH}$ ) saliva merupakan salah satu Faktor penting yang dapat mempengaruhi proses terjadinya demineralisasi pada permukaan gigi. Perubahan $\mathrm{pH}$ saliva dipengaruhi oleh susunan kuantitatif dan kualitatif elektrolit dan kapasitas buffer di dalam saliva. Dalam keadaan normal, $\mathrm{pH}$ saliva berkisar antara 6,8-7,2.Sisa Karbohidrat yang tertinggal di dalam rongga mulut akan difermentasikan oleh bakteri patogen rongga mulut seperti Streptococcus mutans sehingga dihasilkan asam yang akan menurunkan $\mathrm{pH}$ saliva.

Kemudian pada tabel dan gambar 4.3 menunjukkan ada perbedaan $\mathrm{pH}$ saliva sebelum dan sesudahberkumur larutan daun binahong memperlihatkan perubahan yang signifikan. Dimana sebelum berkumur $\mathrm{pH}$ saliva asam sebanyak 30 responden (91\%), dengan kriteria netral sebanyak 2 responden (6\%) dan kriteria basa sebanyak1 responden (3\%) dan setelah berkumur terjadi perubahan $\mathrm{pH}$ saliva walaupun masih dalam kriteria asam sebanyak 18 responden (55\%), kriteria netral 8 responden (24\%), dan kriteria basa sebanyak 7 responden $(21 \%)$.Hal ini disebabkan oleh berbagai Faktor di dalam rongga mulut yang dapat mempengaruhi $\mathrm{pH}$ saliva seperti kecepatan sekresi saliva,mikroorganisme rongga mulut, dan kapasitas buffer saliva.Peningkatan laju aliran saliva akan memengaruhi $\mathrm{pH}$ dalam kadar bikarbonat saliva, semakin banyak aliran saliva maka $\mathrm{pH}$ dan kadar bikarbonat saliva meningkat sehingga kapasitas buffer saliva meningkat. Hal ini dapat diartikan bahwa $\mathrm{pH}$ dan kapasitas buffer saliva meningkat sesuai dengan kenaikan laju kecepatan sekresi saliva (Amerongen, 1991).

$\mathrm{pH}$ ludah yang tidak dirangsang biasanya agak asam, bervariasi dari 6,4-6,9. Konsentrasi bikarbonat pada ludah istirahat adalah rendah, sehingga sumbangan bikarbonat kepada kapasitas buffer paling tinggi $50 \%$, sedangkan pada ludah yang dirangsang dapat menyumbang $85 \%$ dimana $\mathrm{pH}$ ludah parotis naik cepat setelah di stimulasi ringan dari 6,0 sampai 7,0 dan $\mathrm{pH}$ ludah mukus naik 7,0-8,0. Hal ini jelas, bahwa kecepatan sekresi saliva langsung mempengaruhi derajat asam di dalam mulut, dan dengan demikian akan mempengaruhi demineralisasi gigi geligi. (Amerongen, 1991)

$$
\text { Demikian juga dipengaruhi }
$$
keadaaan tertekan pada pasien dapat mengakibatkan penurunan kecepatan 
sekresi demikian juga dengan $\mathrm{pH}$ salivanya, sedangkan padapenderita skizofenia kronis akan terjadi kenaikan kecepatan sekresi demikian juga pHnya karena stimulasi mekanik (teriak), (Amerongen, 1991)

Menurut penelitian terdahulu Assandi (2013) penurunan pH saliva pada masa kehamilan disebabkan oleh perubahan kapasitasbuffer secara fisiologis. Pembesaran perut ibu hamil mengakibatkan respirasi kurangoptimal sehingga kadar $\mathrm{CO} 2$ dalam darah meningkat. Sebagai kompensasi,progesteron meningkatkan sensitivitas sistem respirasi terhadap $\mathrm{CO} 2$ sehingga terjadihiperventilasi. Untuk menjaga keseimbangan asam basa di dalam tubuh, ginjalmenurunkan nilai ambang bikarbonat plasma sehingga terjadi perubahankapasitasbuffer di seluruh cairan tubuh, termasuk saliva. Akibatnya, $\mathrm{pH}$ saliva pada ibu hamil cenderung lebih rendah atau bersifat asam.

Dari hasil tabel 4.4 menunjukkan jumlah data sebanyak 33 orang menunjukkan rata-rata nilai sebesar 6,033 dengan standar deviasi sebesar 0.51425 dapat dijelaskan bahwa nilai hasil observasi memiliki variasi yang kecil sehingga jarak antardata tidak berbeda jauh. Begitupun pada $\mathrm{pH}$ saliva setelah dengan jumlah data sebanyak 33 orang menunjukkan rata-rata nilai sebesar 6.8503 dengan standar deviasi sebesar 0.46080 dapat dijelaskan bahwa nilai hasil observasi memiliki variasi yang kecil sehingga jarak antardata tidak berbeda jauh. Nilai rata-rata $\mathrm{pH}$ saliva sesudah lebih besar dari $\mathrm{pH}$ saliva sebelum menunjukkan bahwa terdapat peningkatan nilai.

Dan hasil pengolahan data padatabel 4.5menunjukkan bahwa adanya pengaruh larutan kumur daun binahong terhadap pH saliva pada ibu hamil, hal ini dapat dilihat dari nilai uji T statistik $\mathrm{pH}$ saliva sebelum dan $\mathrm{pH}$ saliva sesudahdiperoleh nilai $t$ statistic 9.904 dengan nilai $p$-value 0.001 menunjukkan bahwa terdapat perbedaan yang signifikan antara $\mathrm{pH}$ saliva sebelum dan $\mathrm{pH}$ saliva sesudah.Dimana aliran saliva akan meningkat saat dirangsang dengan rasa pahit yang berasal dari daun binahong, rasa pahit tersebut karena daun binahong memiliki kandungan flavonoid, saponin, polifenol, alkanoid, terpenoid, minyak atsiri, dan juga asam oleanik (Istigomah, Santoso, 2015).

Peningkatan kecepatan sekresi biasanya berakibat pada peningkatan $\mathrm{pH}$ dan kapasitas buffernya. Oleh karena itu, membrane mukosa akan terlindung dari asam yang ada pada makanan pada waktu muntah.Dan kecepatan sekresi ludah langsung mempengaruhi derajat asam $(\mathrm{pH})$ dalam mulut, kecepatan sekresi dipengaruhi oleh rangsangan seperti asam, manis, pahit dan pedas (Amerongen, 1991 ; Kidd, Bechal, 1991).

\section{KESIMPULAN}

Berdasarkan dari hasil penelitian pengaruh berkumur larutan daun binahong terhadap $\mathrm{pH}$ saliva pada ibu hamil di Desa Pabentengan Kecamatan Marusu Kabupaten Maros dapat disimpulkan sebagai berikut:

1. Ada pengaruh berkumur larutan daun binahong (Anredera Cordifolia) terhadap $\mathrm{pH}$ saliva pada ibu hamil.

2. pH saliva pada ibu hamil sebelum berkumur larutan daun binahong berada pada kriteria asam dan setelah berkumur larutan daun binahong terjadi perubahan namun tetap berada dalam kriteria asam. 
3. Pada ibu hamil cenderung memiliki kondisi $\mathrm{pH}$ saliva yang asam hal ini dipengaruhi oleh faktor perubahan fisiologis yang menyebabkan terjadinya penurunan $\mathrm{pH}$ saliva. Selain itu perubahan kapasitas buffer, dimana bila kecepatan sekresi menurun maka akan mempengaruhi kapasitas buffer yang menyebabkan terjadinya penurunan $\mathrm{pH}$ saliva.

\section{Saran}

Berdasarkan hasil dan pembahasan penelitian yang dilakukan, maka selaku peneliti dapat memberikan saran sebagai berikut:

1. Diharapkan pada saat hamil tetap menjaga kebersihan gigi dan mulutnya. Dan memeriksakan giginya ke Puskesmas atau tempat pelayanan kesehatan secara berkala setiap 6 bulan sekali, dan sebaiknya tidak hanya berfokus pada pemeriksaan kehamilannya saja.

2. Petugas kesehatan diharapkan tetap meningkatkan dan memberikan pelayanan berupapenyuluhan dan pemeriksaan kesehatan gigi ibu hamil yang pelaksanaanya bekerjasama dengan BKIA guna memberikan pengetahuan kepada ibu hamil seputar kesehatan gigi dan mulut selama masa kehamilan.

\section{DAFTAR PUSTAKA}

Amerongen, A. Van Nieuw. 1991. Ludah Dan Kelenjar Ludah Arti Bagi Kesehatan Gigi.Yogyakarta: Gadjah Mada University Press. Hal, 18-23, 37-38

Assandi, Pratiwi. 20013. Hubungan pH Saliva Dengan Karies Pada Kehamilan Trimester Pertama Dan Kedua. Jurnal Media Medika
Muda Kedokteran Gigi. Semarang: Fakultas Kedokteran Gigi Universitas Diponegoro.

Badan Penelitian dan Pengembangan Kesehatan. 2007. Hasil riset KesehatanDasar 2007. Jakarta: Kementerian Kesehatan RI

Badan Penelitian dan Pengembangan Kesehatan. 2013. Hasil riset KesehatanDasar 2013. Jakarta: Kementerian Kesehatan RI

Bambang, 2018. Manfaat tanaman binahong untuk terapi herbal pada penyembuhan luka.https://id.wikipedia.org/wiki/Bin ahong.

Bandiyah, Siti. 2009. Kehamilan, Persalinan dan Gangguan Kehamilan.Yogyakarta: Nuha Medika.

Bargumono. 2018. Binahong 33 Tanaman TOKA.https://id.wikipedia.org/wiki/B inahong.

Bustami. 2011. Penjaminan mutu pelayanan kesehatan dan akseptabilitasnya. Jakarta: Erlangga. Hal. 93-96

Gendrowati, Fitri. 2018. Tanaman Ajaib Ampuh. Jakarta: Pustaka Makmur. Hal, 26-27.

Haris, Bismi Magfirah. 2017. Efektifitas Ekstrak Daun Binahong, sirsak dan Gabungan Daun Binahong Dengan Daun Sirsak Terhadap Hemostasis Pada Luka Potong Mencit . Skripsi Kedokteran Gigi. Makassar: Fakultas Kedokteran Gigi Universitas Hasanuddin.

Hasibuan, S. 2004. Perawatan Dan Pemeliharaan Kesehatan Gigi Dan Mulut Pada Masa Kehamilan. Skripsi Kedokteran Gigi. Medan: Fakultas Kedokteran Gigi Universitas Sumatera Utara

Heriana, Cecep. 2015. Manajemen Pengolahan Data Kesehatan Bahan Ajar Mata Kuliah Manajemen Data Kesehatan. Bandung: Refika Aditama.

Hermawan, Rudi. 2010. Menyehatkan Daerah Mulut Cara Praktis Menghilangkan Bau Mulut Disertai Tips Agar Gigi Dan Mulut Anda Selalu Sehat Dan Indah.Yogyakarta: Buku Biru. Hal, 190-193.

Houwink, B, dkk. 1993. IImu Kedokteran Gigi Pencegahan. Yogyakarta: Gadjah Mada Univerity Press. 
Istiqomah, Nurul,. Santoso, Bedjo. 2015.Pengaruh Berkumur Larutan Daun Binahong Terhadap $p H$ Saliva Pada Ibu Hamil Desa Babadan Kabupaten Semarang.Jurnal. Poltekkes Kemenkes Semarang, Volume 4 Nomor 9. ISSN 2089-7669

Kasuma, Nila. 2015. Fisiologi dan Patologi Saliva. Padang: Andalas University Press. Hal, 1,6-21

Kementerian Kesehatan RI. 2012. Pedoman Pemeliharaan Kesehatan Gigi Dan Mulut Ibu Hamil Dan Anak Usia Balita Bagi Tenaga Kesehatan Di Fasilitas Pelayanan Kesehatan.Jakarta.Hal, 5-17

Kidd,. Edwina A.M, Bechal, Sally Joyston. 1991. Dasar-dasar karies penyakit dan penanggulangannya. Jakarta: EGC. Hal.73-74.

Maryati. 2000. Derajat Keasaman (pH) Saliva Pada Rongga Mulut
Berkaries Dan Ridak

Berkaries.Skripsi Kedokteran Gigi.

Fakultas Kedokteran Gigi

Universitas Sumatra Utara. Medan

Ritha. 2002. Hubungan Antara Usia Kehamilan Dengan pH Saliva. Skripsi Kedokteran Gigi. Makassar: Fakultas Kedokteran Gigi Universitas Hasanuddin.

Situmeang, Tesalonika Pratiwi. 2017. Efektivitas Berkumur Larutan Air Kemasan Alkaline lonized Water (AIW) Terhadap Perubahan $\mathrm{pH}$ Saliva Dan Jumlah Koloni Bakteri Dalam Saliva. Skripsi Kedokteran Gigi. Makassar: Fakultas Kedokteran Gigi Universitas Hasanuddin.

Sundoro, Edi Hartini. 2007. Serba-Serbi IImu Konsevasi Gigi. Jakarta: UIPress. Hal, 61-62, 73

Yanti, Damai. 2017. Konsep Dasar Asuhan Kehamilan. Bandung: Refika Aditama. Hal, 9-11 